\title{
JESUÍTAS E EMBATES PARA A INCULCAÇÃO DA EDUCAÇÃO E DA CULTURA EUROPEIA NA AMÉRICA PORTUGUESA
}

\author{
Jéssica Cristine de Melo ${ }^{1}$ \\ Paulo Romualdo Hernandes ${ }^{2}$ \\ UNIFAL
}

\begin{abstract}
RESUMO
O presente artigo analisa os embates que os jesuítas enfrentaram para a inculcação da cultura e da educação europeia na terra dos brasis. A partir da leitura e análise de alguns documentos jesuíticos, percebe-se que houve resistência por parte dos nativos das matas à interferência dos religiosos em sua cultura e educação. Aconteceram, também, conflitos no interior da Companhia de Jesus e mesmo entre religiosos de outras ordens e hierarquias da Igreja Católica para a realização de um modo de educar realista, iniciado por Nóbrega, de enfrentamento da realidade brasileira, que Saviani nomeou pedagogia brasílica.

Palavras-chave: pedagogia brasílica; jesuítas; Brasil século XVI; processos de aculturação.
\end{abstract}

\section{JESUITS AND THE CONFLICTS IN THE INCULCATION OF CULTURE AND EUROPEAN EDUCATION IN PORTUGUESE AMERICA}

\begin{abstract}
This article examines the conflicts faced by Jesuits in the inculcation of culture and European education in the land of brazils. From the reading and analysis of some Jesuit documents, it is clear that there was resistance from the natives to the interference of religious people in culture and education. There were also conflicts within the Companhia de Jesus and even among religious of other orders and hierarchies of the Catholic Church to carry out a realistic educate mode, introduced by Nobrega, of coping the Brazilian reality, which Saviani named brasilic pedagogy.
\end{abstract}

Keywords: brasilic pedagogy; Jesuits; Brazil $16^{\text {th }}$ century; processes of acculturation.

\section{Introdução}

Saviani (2008, p. 6), em "História das Ideias Pedagógicas no Brasil", denota a palavra "pedagogia" e mais especificamente seu adjetivo "pedagógico" como o modo de operar, de realizar o ato educativo. Desse modo, ele entende que as ideias pedagógicas dos jesuítas no período colonial não podem ser circunscritas como mera derivação da concepção religiosa católica, ou seja, reduzidas à catequese, mas se estabeleceram como práticas educativas elaboradas para fins de incorporação da América Portuguesa ao Império Português. Os jesuítas tiveram forte apoio de Dom João III para a instituição regulamentar da ordem Companhia de Jesus junto à Santa Sé, e o rei obteve apoio do papa Paulo III para enviar os soldados de Cristo às suas colônias, a fim de converter os habitantes nativos ao cristianismo, mas também torná-los portugueses e súditos do reino português (HERNANDES, 2010). O rei almejava, ainda, que os missionários recuperassem os colonos que estavam afastados da fé, trazendo-os de volta para o seio da Igreja Católica, da qual o Império Português tinha por 
parte do papa o reconhecimento do padroado régio (ASSUNÇÃO, 2004), e assim rememorálos que eram súditos do reino. Portanto, colonização, catequese e educação são elementos que se entrelaçam no período colonial brasileiro (SAVIANI, 2008).

Esse entrelaçamento aconteceu em um palco real, concreto, que foi a América Portuguesa do século XVI, arena em que os jesuítas enfrentaram a realidade e a cultura das matas, das selvas, de habitantes com cultura mais que milenar. Nesse embate de culturas nasceu o que Saviani nomeou de "pedagogia brasílica", um modo de operar a educação, de intervir na prática educativa do Novo Mundo, de enfrentar a realidade das matas (SAVIANI, 2008) de forma singular, que torna o estudo da ação educativa dos jesuítas na terra dos brasis de fundamental importância para a história da educação brasileira. Como afirmam Bittar e Ferreira (2007), há muito a ser descoberto, com novos documentos, e "redescoberto", com novos métodos de estudo, sobre a elaboração da pedagogia realizada pelos jesuítas no período inicial de seu estabelecimento na América Portuguesa.

O estudo aborda, ainda, a tentativa e os embates para a implantação na América Portuguesa da cultura escolar, na acepção que lhe dá Dominique Julia (2001): um modo de educar que afasta o educando da comunidade a fim de formá-lo, conformá-lo, aculturá-lo. Recolhimento de crianças, sobretudo das classes populares, para discipliná-las e adestrá-las à fé e moral cristã (FAVACHO, 2008). Segundo Julia (2001, p. 9), a cultura escolar é um "conjunto de normas que definem conhecimentos a ensinar e condutas a inculcar, e um conjunto de práticas que permitem a transmissão desses conhecimentos e a incorporação desses comportamentos". Julia também entende que a cultura escolar não pode ser estudada sem a análise precisa de outros conjuntos culturais, como a cultura política, cultura religiosa e cultura popular. Assim, o presente artigo deseja entender quais eram os discursos educacionais dos jesuítas e como eram realizadas suas práticas na tentativa de inculcação da cultura e da educação europeia tendo como instrumento a escola, como surgia em Portugal, mas em meio à Mata Atlântica, entre aldeias, aldeamentos, o que provocou enfrentamentos, embates, que serão analisados, sobretudo, com apoio de cartas de Manoel da Nóbrega e de José de Anchieta.

\section{As letras e as armas: aculturação, colonização e resistência}

A história da educação na América Portuguesa teve como protagonistas, no seu início, os religiosos da Companhia de Jesus. No ano de 1549, os primeiros jesuítas chegaram ao porto da Bahia, enviados e financiados pelo rei de Portugal, Dom João III. Seis religiosos vieram na mesma embarcação do primeiro governador-geral, Tomé de Sousa. Foram liderados por Manoel da Nóbrega, que se tornaria, em 1553, o primeiro provincial da Companhia de Jesus no Brasil. Dava-se início ao processo de aculturação, pelas "letras", que seguia par e passo o processo de colonização, pelas "armas" (FERREIRA; BITTAR, 2004).

No primeiro contato, nos primeiros encontros com os seres do Novo Mundo, relatados nas cartas, os discursos jesuítas revelam aquilo que seus olhos ou pareciam não ver ou que não queriam ver: para eles, os índios não possuíam cultura, eram "papel em branco" e, a eles, soldados de Cristo, caberia a missão de transmitir a verdadeira cultura: a cultura europeia, sobretudo pautada nos ensinamentos da fé católica. Essa concepção de Nóbrega sobre os índios pode-se observar no trecho da carta seguinte:

Aca pocas letras bastan porque todo es papel em blanco, e não ha que se fazer outra cousa, sinão escrever á vontade as virtudes mais necessarias e ter zelo em que seja conhecido o Creador destas suas creaturas. [Carta de Pe. Manuel da Nóbrega a ao Dr. Navarro, seu mestre em Coimbra - Salvador, 1549] (LEITE, 1954 a, p. 142) 
Entretanto, com a experiência nas terras da América Portuguesa, pode-se observar que os jesuítas perceberam que os índios, chamados pelos jesuítas de gentios, possuíam costumes muito diferentes dos deles, e logo os atrelaram ao profano. Acreditaram, então, que os índios possuíam cultura, mas não religião. De acordo com Héléne Clastres (1978, p. 15), os primeiros relatos dos jesuítas "dizem-nos que eram os tupis gente ignorante de toda divindade, sem adorar nenhum ídolo, sem em nada reconhecer a dimensão do sagrado, agindo em tudo segundo o bel-prazer, sem que nenhuma obrigação ritual viesse ordenar a sua atividade cotidiana nem ritmar seu tempo". Diziam os jesuítas que o alfabeto indígena não tinha a letra f, pois os índios não tinham fé (VASCONCELOS, 1943). O convívio com os índios proporcionou uma nova visão sobre eles, possibilitando ver costumes arraigados de uma tradição nada semelhante à católica e uma religião dominada, no entendimento deles, por práticas infernais, inscrita na alma dos índios pelo diabo desde tempos imemoriais. Práticas que tinham nos mais velhos e velhas das tribos e, sobretudo, nos caraíbas os seus principais mantenedores e propagadores (HERNANDES, 2008). Os maus costumes e os rituais religiosos infernais, como eram conhecidos os costumes e os rituais dos tupis pelos jesuítas, manifestavam-se na nudez, na poligamia, nas festas com bebedeira de cauim, na antropofagia, na recepção aos caraíbas. Esses eram os embates que os jesuítas enfrentavam na América Portuguesa, tão diferente da luta que seus companheiros de ordem religiosa enfrentavam na Europa, sobretudo com outros religiosos cristãos adeptos da Reforma da Igreja.

A militância dos jesuítas estava pautada nos "Exercícios Espirituais" de Inácio de Loyola, fundador da Companhia de Jesus ${ }^{3}$. Como a Companhia era uma ordem missionária, o seu objetivo maior era recrutar soldados para Cristo a fim de salvar o mundo da vida material, dos pecados da carne, para se alistarem ao exército, espiritual, de Cristo, juntando-se ao exército de um Rei temporal, defensor da Igreja Católica (LOYOLA, 1966). Segundo Serafim Leite (2004), o lema de Inácio de Loyola era tudo para a maior glória de Deus, frase que aparece várias vezes em seus escritos. Com esse regime de verdade, os jesuítas vieram para a América Portuguesa e enxergavam os nativos das matas como afastados de Deus, aliados dos demônios, não conhecedores da salvação, por isso desejavam arduamente sua conversão, já que eram pagãos e não infiéis. No entanto, esse desejo constituído por saberes e práticas de cultura de mais de mil anos e em outro espaço entraria em confronto com a realidade, com a cultura e com a religião mais que milenar, também, indígena. Em carta de junho de 1557, António Blasquez, escrevendo a Inácio de Loyola, que já havia morrido nesse momento, descreve uma cena em uma aldeia que nos revela, na descrição de um padre jesuíta, o embate de culturas e educação. Diz Blasquez: "vinhão seis molheres nuas polo terreiro cantando a seu modo e fazendo tais gestos e meneos que parecião os mesmos diabos" (LEITE, 1554b, p. 385). Segundo o religioso, essas mulheres estavam enfeitadas de penas vermelhas e amarelas e, para alegrar a festa, tangiam umas flautas que têm feitas das canelas dos contrários para quando hão de matar prisioneiros. Ladravam como cães e, contrafazendo a fala, faziam tantos momos que não "sey a que os possa comparar; todas estas invenções fazem sete ou oito dias antes de hos matar" (LEITE, 1554b, p. 386). Estavam os religiosos na aldeia do Rio Vermelho, onde, para entrar, precisaram contar com a ajuda dos meninos órfãos e dos meninos índios: "e asi entrarão em procissão cantando, do que eles maravilharão e ficarão como atônitos porque em estremo são dados à música e ouvir cantar" (LEITE, 1554b, p. 384). No interior da aldeia encontraram os principais reunidos com a "gentilidade" para matarem contrários que haviam capturado; eram sete. Os jesuítas nem tentaram dissuadir de os índios matarem esses inimigos que tinham feito prisioneiros, mas tentaram salvar a alma daqueles sete que seriam mortos, com a água do batismo, que limpa todas as "sujidades". Nesse momento, reproduzo a escrita de Blasquez: 
E porque o demônio não enganasse a estes sete que estavão em esta Aldea com semelhantes enganos, João Gonçalves despois que os trouxerão ao corro os foi a aparelhar e pretentar se querião ser christãos, dizendo-lhes que até li forão filhos do diabo e que ele vinha da parte de Deos pera os fazer seus filhos, se eles com arrependimento da vida passada quisessem receber o batismo, suficentíssimo pera lhes lavar toda a sugidade de seus pecados e tornar a alma limpa que eles com sua topeza tinhão negra e mui fea; acrescentando a isto que os demônios não aguardavão outra cousa senão que espirassem pera os levar ao inferno, do qual escaparião se antes de morrer se lavassem com o sagrado bautismo. Com isto e com outras cousas que o Spirtu Santo lhes inspirou ficarão todos movidos (somento hum) pera receber nossa fee. E nós outros com este contentamento nos tornamos pera casa dando louvores ao Senhor por se dignar de alumiar estes que estavão tão propínquos a ser comidos daquela besta infernal. [carta do padre Blasquez por comissão do padre Nóbrega ao padre Inácio de Loyola, Bahia, junho de 1557 (LEITE, 1954b, p. 387)]

Os jesuítas traziam de sua formação intelectual os saberes cristãos do século XVI da Europa, de popularização da doutrina, regimes de verdades, e com eles queriam dominar, subjugar e submeter os nativos do Novo Mundo ao seu poder. Desse modo, com o poder do seu discurso, tentaram convencer e mesmo impor aos índios a cultura europeia, desqualificando aspectos importantes de sua cultura, ou religião, como a antropofagia, a poligamia, também seus rituais, suas beberagens de cauim, suas danças e a morte de inimigos. Queriam os padres da Companhia que os nativos acreditassem que o que eles adoravam ou cultuavam era obra do inimigo da natureza humana, do diabo. No entanto, os indígenas prisioneiros da aldeia do Rio Vermelho resistiam ao discurso dos padres, mas não resistiam à morte, não buscavam salvação com os padres, pois o medo da morte para eles, segundo o relato, nos parece que indignado, do próprio padre Blasquez, significava que eram "fracos e apoucados", enquanto participar de toda a cerimônia que os levaria à morte era sinal de que eram valentes e esforçados (LEITE, 1954b, p. 386). Os jesuítas não entendiam esses rituais como pertencentes a outra cultura religiosa e acreditavam que eram práticas infernais. $\mathrm{Na}$ leitura da carta, nas entrelinhas do discurso do padre para a fala dos prisioneiros a quem queriam salvar, é possível perceber que o que não fazia sentido para eles era o inferno, o diabo, e não morrer como valente. Nesse episódio relatado acima, como não conseguiram dissuadir os índios da aldeia de matarem e devorarem os contrários, nas letras, contaram com a ajuda do Governador, pelas armas, que mandou invadir a aldeia e fazer com que os índios deixassem os padres batizar seus inimigos e os enterrar.

Segundo Foucault (2008), os discursos do Mesmo (dos jesuítas) procuram impor aos Outros (aos nativos) regimes de verdade. No entanto, discurso é poder, mas também é resistência. De um lado da corda, os jesuítas tentavam impor a cultura e religião católica e portuguesa; do outro lado, os índios resistiam ${ }^{4}$ para manter seus costumes, sua religião. Os nativos das matas resistiram de variadas formas, desde a criação de religiões indígenas com princípios católicos, como o sincretismo da Santidade do Jaguaribe, interpretada por Vainfas ${ }^{5}$ (1995) em "Heresia dos Índios", ou em resistências silenciosas, interpretadas por Clastres ${ }^{6}$ (1995) em "Crônica dos Índios Guayaki”, ou em Todorov" "Conquista da América" (2010), em que estes forjavam que haviam se convertido, mas continuavam a praticar os seus costumes, misturados com o que aprendiam com os padres. Essa resistência se pode perceber, também, nas cartas dos jesuítas, que sempre enfatizavam a dificuldade dos índios de se manterem firmes na fé católica, com o que eram chamados de inconstantes. José de Anchieta foi o primeiro a utilizar esse termo da inconstância ao falar dos gentios:

Nenhum fruto, porém, tirando disso, mas antes observando que continuavam os maiores escândalos por causa do indecoroso e dissoluto modo de viver, não só do pai como dos filhos, que estavam amancebados com duas irmãs e parentas, começaram a exercer algum rigor e violência para com eles, expelindo-os sobretudo 
da comunhão da Igreja, os quais, devendo com isso mudar de vida, de tal modo se depravaram que nos perseguiram com o maior ódio, esforçando-se em fazer-nos mal por todos os meios e modos, ameaçando-nos também com a morte, mas especialmente trabalhando para tornar nula a doutrina com que instruímos e doutrinamos os Índios e movendo contra nós o ódio deles. E assim, se não se extinguir de todo este tão pernicioso contagio, não só não progredirá a conversão dos infiéis, como enfraquecerá, e de dia em dia, necessariamente desfalecerá. [Carta do Ir. José de Anchieta - Piratininga, na Casa de S. Paulo, 1554] (ANCHIETA, 1988, p. 57)

Em outra carta de Anchieta a Inácio de Loyola, de setembro de 1554, o jesuíta canarino desabafa:

quando os julgamos ganhos, recalcitram, porque não há quem os obrigue pela força a obedecer; os filhos obedecem aos pais conforme lhes parece; finalmente cada um é rei em sua casa e vive como quer; por isso nenhum fruto, ou menos pequeníssimo, se pode colher deles, se não se juntar a força do braço secular, que os dome e sujeite ao jugo da obediência. (LEITE, 1954b, p. 114)

Em carta de São Vicente, ano de 1560, Anchieta escreve para o padre Laynez, Geral da Companhia de Jesus naquele momento, sua decepção com os meninos que foram ensinados desde pequenos na escola de Piratininga: os "mochachos, que luego en el principio fueron enseñados en la escuela in christianos costumbre [...] como llegaron a los años de puberdade y que tanto sobrepujan ágora a sus padres en maldad cuanto sin frenamento se dan a las borracherias y luxurias" (LEITE, 1954c, p. 262). A religião indígena, propagada pelos mais velhos e pelos caraíbas, tinha como ponto central para os homens a captura e matança de inimigos, em rituais antropofágicos regados a bebedeiras de cauim, o que tornava o homem valente, pois poderia ter muitas mulheres e possibilitaria sua viagem e acesso à terra dos ancestrais (FERNANDES, 1970). Para os jesuítas, esses aspectos centrais da organização da sociedade tupinambá, como beber muito cauim e ter muitas mulheres, não eram mais que luxúrias e bebedeiras, práticas infernais, marcadas nas almas dos índios pelos seus avós em tempos passados, que os fizeram esquecer Deus e que deveriam ser eliminados de sua memória com a rememorização das verdades cristãs (HANSEN, 2005). Afinal, dizia Nóbrega (1988) em "Diálogo da Conversão dos Gentios", os índios são humanos, pois têm as três faculdades da Alma - memória, inteligência e vontade, portanto dignos de serem convertidos e salvos para Deus. Verdade definida pela escolástica, que universalizava o modo de viver cristão, católico e português pelo discurso e que encontraria com a realidade material da vida dos nativos do Novo Mundo embates e resistências sem fim.

Nesse embate entre cultura e educação dos jesuítas com os nativos do Novo Mundo, os caraíbas, certamente, eram os piores inimigos. O discurso jesuítico, de colonizadores, educadores, pelas letras, era a todo o momento confrontado com o discurso dos caraíbas, seres da fala sagrada, segundo Clastres (1990). Os caraíbas, conhecidos nas cartas dos jesuítas também como feiticeiros, eram considerados, pelos índios, como seres que tinham poderes e pregavam a Terra sem $\mathrm{Mal}^{8}$. Segundo Vainfas (1995), os índios acreditavam que os caraíbas eram homens que tinham o poder de conversar com os mortos, com os espíritos ancestrais, pregavam a busca pela Terra sem Mal, terra de bem-aventurança, privilégio que os índios podiam gozar ainda durante a vida. Lá, onde não se morria jamais, eles não necessitariam de trabalhar, encontrariam seus ancestrais e viveriam com festas e danças, segundo o seu costume. No confronto dos discursos jesuíticos, sobretudo nos aldeamentos, com a fala sagrada dos caraíbas, a nheengatu (boa fala), algumas misturas como forma de resistência podem ter acontecido, entre as quais a já citada Santidade do Jaguaribe, cujo caraíba era um índio que havia sido ensinado pelos padres em um aldeamento na Bahia. Na realização do 
culto, da santidade, o caraíba/cristianizado misturava ritos indígenas e cristãos, criando algo híbrido ou até sincrético (VAINFAS, 1995).

Nóbrega, escrevendo da Bahia, em 1549, foi quem primeiro falou e identificou na prática dos caraíbas santidade ao descrever o rito, ao mencionar que "o feiticeiro" fazia crer, ao dialogar com a cabaça, que nela havia "alguma cousa santa e divina" e, ainda, que entrava o espírito da santidade nos possessos. "É certo que, ao utilizar a palavra santidade nessa descrição do rito indígena, Nóbrega estabeleceu certa analogia com o êxtase místico para, em seguida, negá-lo, reputando-o falso, quem sabe diabólico" (VAINFAS, 1995, p. 51). Penso que, por ser uma descrição muito interessante, de Nóbrega, merece ser citada na íntegra:

\begin{abstract}
De certos em certos annos vêm uns feiticeiros de mui longes terras, fingindo trazer santidade e ao tempo de sua vinda lhes mandam limpar os caminhos e vão recebêlos com dansas e festas, segundo seu costume; e antes que cheguem ao logar andam as mulheres de duas em duas pelas casas, dizendo publicamente as faltas que fizeram a seus maridos umas ás outras, e pedindo perdão dellas. Em chegando o feiticeiro com muita festa ao logar, entra em uma casa escura e põe uma cabaça, que traz em figura humana, em parte mais conveniente para seus enganos e mudando sua própria voz em a de menino junto da cabaça, lhes diz que não curem de trabalhar, nem vão á roça, que o mantimento por si crescerá, e que nunca lhes faltará que comer, e que por si virá á casa, e que as enxadas irão a cavar e as frechas irão ao matto por caça para seu senhor e que hão de matar muitos dos seus contrários, e captivarão muitos para seus comeres e promette-lhes larga vida, e que as velhas se hão de tornar moças, e as filhas que as dêm a quem quizerem e outras coisas similhantes lhes diz e promette, com que os engana, de maneira que crêm haver dentro da cabaça alguma cousa santa e divina, que lhes diz aquellas cousas, as quaes crêem. Acabando de fallar o feiticeiro, começam a tremer, principalmente as mulheres, com grandes tremores em seu corpo, que parecem demoninhadas (como de certo são), deitando-se em terra, e escumando pelas bocas, e nisto lhes persuade o feiticeiro que então lhes entra a santidade; e a quem isto não faz tem-lh'o a mal. Depois lhe offerecem muitas cousas e em as enfermidades dos Gentios usam tambem estes feiticeiros de muitos enganos e feitiçarias. [NÓBREGA, Informação das Terras do Brasil, 1549 - grifos meus] (NÓBREGA, 1988, p. 99)
\end{abstract}

Os caraíbas exerciam um poder fecundo sobre os indígenas, segundo alguns jesuítas, entre eles Nóbrega (1988) e Anchieta (1988), e os desconcertavam, pois, como eles próprios, os "feiticeiros" circulavam livremente pelas aldeias levando consigo os discursos da tradição, dos ancestrais e as promessas de uma vida melhor na Terra sem Males. O poder dos caraíbas se distribuía em rede de micropoderes nas aldeias, nas tribos e até nas relações pessoais, o que dificultava muito o trabalho dos padres, pois era um poder que se estabelecia em pequenos grupos e em indivíduos. Por isso a melhor forma que os jesuítas, entre eles Anchieta (1988), entendiam que a missão resultaria em algo produtivo era o recolhimento dos índios nas casas, escolas, ou em grandes aldeias. As comunidades indígenas eram "sociedade sem estado", segundo Clastres (1978, p. 132), sem hierarquias, sem um Rei que submetesse todos à lei, a um poder central. As decisões políticas das tribos eram tomadas pelos mais velhos, em conselho, e os caraíbas tinham papel importante, já que tinham o poder de falar com os ancestrais (FERNANDES, 19-). Talvez por isso, os jesuítas asseguravam que a língua indígena não tinha $\mathrm{L}$, pois acreditavam que entre os povos autóctones das matas não havia lei, tampouco a letra $\mathrm{R}$, afinal os índios não conheciam Rei e, portanto, Estado (VASCONCELOS, 1943). Na percepção deles tratava-se de sociedade incompleta (CLASTRES, 1978), pois não podiam imaginar uma sociedade sem Estado. Não compreendendo uma cultura diferente da sua, os jesuítas procuraram transformar essa cultura, que entendiam como negativa, sem rei, sem lei, sem Estado, na forma como concebiam a sociedade em que o poder do Rei temporal ou de Deus governa a vida de todos e de cada um. 
Nesse ponto encontraram fortes resistências para submeter e subjugar os indígenas pelas letras, as armas foram utilizadas então e os índios foram submetidos em Grandes Aldeias, os aldeamentos, sob as armas do governador e os ensinamentos dos padres.

Nos aldeamentos os índios eram retirados de seus locais, colocados nas aldeias sob o mando do governador e confiados aos jesuítas para serem aculturados. Segundo Cristina Pompa (2003), os aldeamentos construídos a partir de uma nova forma de catequização consistiam na redução ("conduzir", "retirar", "afastar"), retirar os índios do convívio dos outros homens e dos colonos a fim do "bom governo", educação de corpo e alma. E esta era a utopia jesuítica que justificava a colonização. Consistia na produção de corpos dóceis e submissos politicamente (FOUCAULT, 2009) que internalizassem a disciplina para a formação de um sujeito portador da cultura "verdadeira": cultura europeia; conhecedor da "verdadeira" fé: católica; para o objetivo maior de salvação de almas.

\section{Recolhimento de meninos para afastá-los da conversação com sua comunidade}

No regimento de Dom João III ao primeiro governador do Brasil, o poderoso monarca português escreve sobre sua preocupação com a formação dos nativos do Novo Mundo na fé e moral cristã, separando-os em aldeamentos, afastando-os de sua comunidade. Também com o ensino das crianças afastadas da "conversação" com sua comunidade "porque neles se imprimirá melhor a doutrina, trabalhareis por dar ordem como se façam cristãos e que sejam ensinados e tirados da conversação dos gentios" (LEITE, 1954a, p. 4). Prática que se consolidava na Europa, segundo Foucault (2009), para formar sobretudo as crianças de corpo dócil e de mente submissa politicamente. Cultura escolar no sentido de transformar a criança "conforme" (JULIA, 2001, p. 32) o Estado português desejava. Nóbrega, líder da missão da América Portuguesa, em sua chegada, inicia essa tarefa, escolhe o lugar para instalar a escola e nela recolhe meninos índios, mestiços e mais tarde órfãos vindos do reino, para ensinar a ler e escrever. Segundo Faria (2005), ao ensinar os meninos a ler e escrever, conjuntamente se ensinava a doutrina cristã. $\mathrm{O}$ trecho da carta que segue mostra a divisão do trabalho desses padres que, em conjunto, tinham a missão da conversão:

(...) Na cidade reside o padre Antônio Pires, como Reitor da Casa, com o padre Antonio Pires o qual agora tem cuidado de lêr uma classe aos que sabem de latim, e tem tambem a seu cargo as prégações da cidade; ficam com Antonio Blasques os que menos sabiam; ha na mesma Casa, assim mesmo, eschola de lêr e alguns meninos do Gentio, e com eles se ensinam outros da cidade, e de todos tem cuidado um Irmão; [Carta de Pe. Manuel da Nóbrega ao Provincial de PortugalPernambuco-1557] (NÓBREGA, 1988, p. 171)

Nessa carta de Nóbrega, percebem-se os embates entre educação e cultura, sobretudo a cultura escolar. Os meninos índios deixavam suas aldeias, lugar em que eram educados por seus pais e pela comunidade, e passavam a ser recolhidos pelos padres nas escolas de "ler" para serem cuidados por um Irmão, apartados de sua cultura e de sua educação. Trata-se de atividade educativa totalmente nova para meninos habituados a aprenderem a cultura de sua tribo junto a seus pais, empiricamente (SAVIANI, 2008). Aculturação que pretendia marcar o corpo e a mente das crianças, preparados, disciplinados, quietos, para ler ou para prestar atenção no que o padre lia. 
Anchieta fala da preparação das crianças a serem ensinadas na escola e se tornarem um povo agradável a Cristo:

Estes, entre os quais vivemos, entregam-nos de boa vontade os filhos para serem ensinados, os quais depois, sucedendo a seus pais, poderão constituir um povo agradável a Cristo. Na escola, muito bem ensinados pelo Mestre António Rodrigues, encontram-se 15 já batizados e outros, em maior número, ainda catecúmenos. [Carta do Ir. José de Anchieta a Pe. Inácio de Loyola, setembro de 1554] (LEITE, 1954b, p. 106)

De acordo com Dominique Julia (2001, p. 9), a cultura escolar é um "conjunto de normas que definem conhecimentos a ensinar e condutas a inculcar, e um conjunto de práticas que permitem a transmissão desses conhecimentos e a incorporação desses comportamentos". Como já falado na introdução, de acordo com Julia, não se pode fazer uma análise da cultura escolar desprezando as outras instâncias culturais. No período colonial, essa análise torna-se ainda mais pertinente, pois não existe separação entre Estado, Igreja e Educação (FERREIRA; BITTAR, 2004). Desse modo, essa casa de be-á-bá não funcionava apenas como lugar de saberes, mas como lugar de inculcação de pensamentos, de crenças e de comportamentos. Segundo Foucault (2009), em seu livro "Vigiar e Punir", o colégio desse período funcionava sob o princípio da clausura, lugar de "quadriculamento", onde o indivíduo sai do mundo dos prazeres da carne, do demônio e de seus enganos e vai para um local de isolamento - lugar que será vigiado, controlado e disciplinado continuamente. Cultura escolar que se impunha na Europa de revoluções na educação, sobretudo das classes populares, com as novas formas de devoção, a devotio moderna, também com a Reforma. Os jesuítas campeões na propagação dessa nova cultura escolar (MANACORDA, 2006), na Europa, tentaram impô-la na América Portuguesa, sobretudo entre as crianças, pois, segundo Nóbrega, não estavam tão arraigadas no que eles chamavam de maus costumes:

\footnotetext{
Visitei algumas aldeias deles e acho-lhes bons desejos de conhecer a verdade; e instavam para que ficasse no meio delles, e si bem que seja difícil fazer desarraigar aos mais velhos as suas más usanças, com os meninos, porém, se póde esperar muito fructo, porque não se oppõem quasi nada á nossa lei e assim me parece que esteja aberta a porta para muito ajudar as almas nesta terra (ainda que aquelles que dicunt bonum malum, et malum bonum, pensem diversamente), pois que não têm feito resistencia nem matado aos que queiram fazel-os christãos e se deixam arrastar para a Fé, comquanto não sejam induzidos pelos Christãos que aqui vêm com o exemplo ou com a palavra ao conhecimento de Deus, mas antes os chamam cães e fazem-lhes todo o mal. [Carta de Pe. Manuel da Nóbrega ao Padre Simão Rodrigues- Porto Seguro, 6 de Janeiro de 1550] (NÓBREGA, 1988, p. 107)
}

Retirar as crianças autóctones de junto aos seus, da educação de seus pais, de sua cultura, para educá-las segundo um modo de vida cristão, de obediência, de disciplina, de sujeição às hierarquias, ao padre, a Deus, ao Governador. A obediência às hierarquias, "centrada na religião" (PAIVA, 2000, p. 44), e a disciplina eram elementos importantes utilizados na pedagogia dos jesuítas. No entanto, o recolhimento dos meninos índios para melhor adestra-los a moral e a doutrina cristã trouxera, talvez, o primeiro problema para a escola na América portuguesa. As Constituições da Companhia de Jesus proibiam recebimento de rendas para Colégios que não fossem Canônicos. Também os colonos não viam com bons olhos as conquistas de Nóbrega junto ao Governador, terras, escravos e vacas de leite, para a manutenção dos meninos, com que concordara o primeiro Bispo da América Portuguesa.

\section{Conflito entre religiosos na manutenção da escola para recolhimento de meninos índios}


O recolhimento de crianças, sua manutenção, sob a tutela dos padres para pedagogia da disciplina e da obediência às hierarquias, encontrou forte resistência entre os religiosos que não aceitavam o plano realista de Nóbrega para a catequese, evangelização e aculturação indígena. Podemos destacar alguns indícios dos embates nas relações de poder dentro do próprio grupo de jesuítas, visto que era formado por uma forte hierarquia de poder e de resistências, no caso de Nóbrega com Luiz da Grã, seu colateral. Também houve embates com hierarquias da Igreja Católica, caso dos atritos de Nóbrega com o primeiro bispo da América Portuguesa, Dom Pedro Fernandes Sardinha.

Podemos observar nas cartas de Nóbrega seus atritos com o bispo Fernandes Sardinha. Segundo Serafim Leite (2004), o bispo era muito esperado por Nóbrega; entretanto, quando chegou à América Portuguesa, começou a indagar sobre as posses dos colégios, sobre a "renda para manutenção dos meninos" (LEITE, 1954a, p. 362), e Nóbrega começou a escrever para Portugal como forma de justificar que os bens que o colégio possuía eram de extrema necessidade para a manutenção do colégio e das casas dos meninos, sem o que esses meninos voltavam à sua velha vida (LEITE, 1954a). Todavia, o bispo passou a levantar outras questões e a desautorizar os padres em ambientes particulares e também em público. Em suas pregações, chegou a condenar a catequese dos jesuítas, que permitiam que os índios entrassem nas igrejas junto com os cristãos, que se confessassem com intérpretes, que fizessem orações em tupi, entre outras obras realizadas pelos jesuítas que lhe causavam estranheza (LEITE, 1954a).

Em 1556, a Coroa chamou à corte de Lisboa o bispo D. Fernandes Sardinha. Pouco depois da sua partida da Bahia, em junho de 1556, Sardinha e seus companheiros naufragaram em Cururipe, nas vizinhanças do São Francisco. Os náufragos puderam salvar-se, mas foram assassinados e devorados pelos caetés. O bispo Sardinha, devorado pelos índios, foi um grande opositor da atividade jesuítica na Bahia. Suas ideias sobre a missão entre os nativos encontravam-se em oposição direta aos esforços dos jesuítas e eram compatíveis com a posição dos colonos (FARIA, 2005). Nóbrega escreveu após a morte do bispo demonstrando que sua presença havia dificultado o trabalho, sobretudo para a "salvação" do gentio:

Trouxe Nosso Senhor o bispo D. Pedro Fernandes, tal e tão virtuosos qual Vossa Mercê conheceu, e mui zeloso da reformação dos costumes dos Cristãos, mas quanto aos Gentios e sua salvação se dava pouco, porque não se tinha por seu Bispo, e eles lhes pareciam incapazes de toda doutrina por sua bruteza e bestialidade, nem as tinha por ovelhas de seu curral, nem que Christo Nosso Senhor se dignaria de as ter por taes; mas nisto me ajude Vossa Mercê a louvar a Nosso Senhor em sua providência, que permitiu que fugindo ele dos Gentios e da terra, tendo poucos desejos de morrer em suas mãos, fosse comido d'eles e a mim que sempre desejei e pedi a Nosso Senhor, e metendo-me nas ocasiões mais que ele, me foi negado. O que eu nisso julgo, posto que não fui conselheiro de Nosso Senhor, é quem isto fez, porventura quis pagar-lhe suas virtudes e bondade grande, e castigar lhe juntamente o descuido e pouco zelo que tinha da salvação do Gentio. (NÓBREGA, 1988, p. 193)

O plano de Nóbrega para a transformação cultural do Brasil não "deixava de conter uma preocupação realista" (SAVIANI, 2008, p. 43), que o bispo não entendia ou não queria entender. Segundo Nóbrega, não havia como doutrinar as crianças sem retirá-las da convivência de sua comunidade. O Bispo, por sua vez, não via os indígenas como seu rebanho, não os via como possibilidade de virem a ser cristãos e, portanto, não compreendia a 
insistência de Nóbrega na manutenção dos meninos no colégio, com a ajuda do governador para obter rendas para manter os meninos.

Os conflitos de obediência às hierarquias no interior da ordem eram vários, revelados por cartas, embora muitas tenham sido censuradas ${ }^{9}$. As hierarquias e a obediência são formas do poder disciplinar, segundo Foucault (2009). Poder que se distribui entre os membros da ordem jesuítica, nos colégios, nas missões. Como redes de poderes, as hierarquias e a obediência têm suas microrresistências. Na América Portuguesa, o conflito de poderes se deu entre o primeiro Provincial da Companhia de Jesus, Nóbrega, e o seu Colateral, Luiz da Grã, que seria o segundo provincial. Muitos eram os motivos, mas um deles se referia às adaptações que Nóbrega fazia para estabelecer a missão na terra dos brasis, dentre as quais obter rendas para a manutenção de crianças nos colégios da Companhia. Nóbrega, desde o início de sua missão, havia conseguido rendas junto ao primeiro governador, Tomé de Souza, para construir os colégios e manter os meninos índios, mestiços e órfãos vindos do reino, pois achava ser essa a melhor maneira de doutriná-los e modificar os costumes. Luiz da Grã era contra, pois denunciava ao provincial de Portugal, Miron, que Nóbrega estava contrariando as Constituições da Companhia, que não permitiam que se tivesse renda que não fosse para os Colégios Canônicos. Embora Nóbrega tivesse apoio de Simão Rodrigues e Diogo Laynez, dois fundadores da Companhia, ao que tudo indica perdeu o embate, já que Luiz da Grã tornou-se provincial em seu lugar e os colégios que recolhiam, abrigavam e mantinham os meninos índios, mestiços e órfãos vindos do reino se tornaram colégios canônicos, a exemplo do Colégio dos Meninos de Jesus, de Salvador, que se tornou Colégio de Jesus. Aos meninos índios o mesmo destino de seus pais, confinados em grandes aldeias, aldeamentos, sob o jugo do Governador. Os meninos viviam vida híbrida, trabalhando em busca de seu alimento, junto com sua comunidade; e, nas horas livres, tinham de se dirigir à escola dos padres na aldeia ou aldeamento (ANCHIETA, 1988).

No entanto, mesmo destituído do cargo de provincial da Companhia, substituído por seu desafeto, Grã, Nóbrega continuou buscando rendas para a manutenção dos meninos. Criticado por Luiz da Grã, escreve em Carta a Diogo Laynez, no ano de 1561, "si nosotros no los sustentamos y miramos por ellos, assi em lo temporal con en lo spiritual, se perde la obra". Embora Nóbrega devesse obediência ao provincial, segundo a hierarquia da Companhia de Jesus, a missão falava mais alto e a realidade da vida nas matas o obrigava e agir de modo diferente de como faria em Portugal. Admite para o Geral da Companhia, em Roma, também ele queria converter "esta gente da misma manera que S. Pedro y los Apóstolos hizieron, y como S. Francisco ganõ a muchos por penitência y exemplo de pobreza, no entanto, escreve Nóbrega, com seu realismo costumeiro, que a opinião de Grã o havia feito pensar muito e fincar pé nestas coisas até resolver de modo contrário, salvo sempre o que determinava a santa obediência, que a "Companhia deve tener y acquirir justamente, por médios que las Constituitiones permitem" quanto puder para manter os "Colegios e Casas de mochachos" e que "no devemos de querer que siempre o Rei nos provea (LEITE, 1954c, p. 365). Ou seja, a Companhia de Jesus na América Portuguesa devia produzir o que fosse necessário para a manutenção das casas e colégios, usando escravos, e não depender de esmolas e da provisão do Rei. Na resposta de Laynez a Nóbrega, esse se diz favorável à manutenção dos meninos se for para a maior glória de Deus (LEITE, 1954c).

\section{Considerações finais}


Os jesuítas, por meio de um discurso pautado na salvação de almas, foram peças fundamentais para o início da história da educação no Brasil. Foram eles os primeiros professores; criaram uma pedagogia própria para alcançar êxito em sua missão, a pedagogia brasílica, e assim enfrentaram os embates entre a educação e a cultura que trouxeram de alémmar com a educação e a cultura dos povos autóctones das matas. Por meio da experiência em terras brasílicas, adaptaram e até mesmo modificaram seus próprios pensamentos e próprias atitudes na relação com os índios. Fundaram, segundo Saviani (2008), uma pedagogia, a brasílica, esse ato educativo que mistura aspectos da cultura nativa para o ensino da moral e fé cristã. Essa pedagogia brasílica enfrentou fortes embates entre os jesuítas, sobretudo Grã e Nóbrega, o primeiro legalista, não aceitava a manutenção de meninos nas escolas, pois que isso feria as normas da Companhia e Nóbrega, realista, que queria realizar a missão a qualquer custo. Também encontrou fortes resistências do Bispo que não aceitava as adaptações que os primeiros jesuítas fizeram para sua obra missionária, sobretudo porque não via os índios como seu rebanho.

Segundo Faria (2005), o ato educativo dos jesuítas, ou seja, a aculturação, não exigia uma transformação total dos costumes, mas apenas daqueles que não se conformavam com os parâmetros europeus. Essa adaptação dos padres à cultura local, liderados por Nóbrega, tem a ver com o enfrentamento da realidade, com a vida nas matas, para poder realizar a missão de evangelização. Nóbrega elaborou um ato educativo que tinha como primeira intenção a "sujeição dos gentios, sua conversão à religião católica" (SAVIANI, 2008, p. 44). Para tal missão, os primeiros jesuítas conservaram aspectos importantes da cultura nativa que não contrariavam a religião e fé católica, como a sua dança, os seus cantos, o uso de instrumentos e, sobretudo, a língua. Criaram orações, sermões e catecismos na língua tupi para ensinar conteúdos cristãos. José de Anchieta foi o expoente máximo dessa tarefa, criando já em 1556 a "gramática da língua mais falada do Brasil", produzindo catecismos, peças de teatro, doutrinas, orações em tupi, misturando elementos da cultura nativa à cultura cristã. Algo singular e inesperado, mas que segue, segundo Ferreira e Bittar, uma lógica simples: a catequese, de tão imperiosa que era, "suscitou uma situação sui generis: a tentativa de inversão de requisitos exigidos para a formação de padres, ou seja, em vez da teologia como prioridade, o aprendizado da língua brasílica" (FERREIRA; BITTAR, 2004, p. 182), em vez de Colégios Canônicos, casas e escolas para recolhimento de meninos (FAVACHO, 2008). Com uma pedagogia baseada na disciplina e no exemplo, trataram de formar corpos dóceis moldados sob a perspectiva da cultura europeia e sob a óptica da fé cristã. Os colégios inicialmente e depois as escolas nas aldeias e aldeamentos jesuíticos formavam esses indivíduos. No entanto, essa formação de corpos dóceis e mentes submissas politicamente (FOUCAULT, 2009), desejada pelos jesuítas, recebeu fortes resistências, sobretudo dos indígenas, mas que somente podemos perceber nas entrelinhas dos discursos dos padres, pois é por meio desses discursos que interpretamos essas resistências.

\section{Referências}

ANCHIETA, J. Cartas, informações, fragmentos históricos e sermões (1554-1594). Belo Horizonte: Itatiaia: São Paulo: Editora Universidade de São Paulo, 1988.

ASSUNÇÃO, P. Negócios jesuíticos. O cotidiano de Administração dos bens Divinos. São Paulo: Editora da Universidade de São Paulo, 2004. 
BITTAR, M.; FERREIRA, A. A pesquisa em história da educação colonial. In: PAIVA, J. M.; BITTAR, M.; ASSUNÇÃO, P. (Org.). Educação, história e cultura no Brasil colonial. São Paulo: Arké, 2007.

BOSI, A. Dialética da colonização. São Paulo: Companhia das Letras, 1992.

CLASTRES, P. A Sociedade contra o Estado: pesquisa de antropologia política. Tradução de Theo Santiago. Rio de Janeiro: Francisco Alves, 1978 (Ciências Sociais).

CLASTRES, P. A fala sagrada. Tradução de Nícia Adan Bonatti. Campinas: Papirus, 1990.

CLASTRES, P. Crônica dos índios guayaki. Tradução de Tânia Stolze Lima e Janice Caiafa. Rio de Janeiro: Editora 34, 1995.

CLASTRES, H. Terra sem mal. Tradução de Renato Janini Ribeiro. São Paulo: Brasiliense, 1978.

FARIA, M. R. As representações de escola, ensino e aluno nas cartas de Manuel da Nóbrega, José de Anchieta e Antonio Blásquez (1549-1584). Dissertação (Mestrado em Educação) - Pontifícia Universidade Católica de São Paulo. São Paulo, 2005.

FAVACHO, A. O recolhimento dos meninos. Por uma genealogia da ordem pedagógica brasileira. Tese (Doutorado) - Universidade de São Paulo. São Paulo, 2008.

FERNANDES, F. A Função Social da Guerra Na Sociedade Tupinambá. 2. ed. São Paulo: Livraria Pioneira Editora, Editora da Universidade de São Paulo, 1970.

. A Organização Social dos Tupinambá. São Paulo: Instituto Progresso Editorial, 19-.

FERREIRA JÚNIOR, A.; BITTAR, M. Pluralidade lingüística, escola de bê-a-bá e teatro jesuítico no Brasil do século XVI. Educação e Sociedade, v. 25, n. 86, p. 472-482, 2004.

FOUCAULT, M. A ordem do discurso. São Paulo: Loyola, 2008.

FOUCAULT, M. Vigiar e punir nascimento das prisões. Tradução de Raquel Ramalhete. 36.ed. Petrópolis: Vozes, 2009.

HANSEN, J. A. O nu e a luz: cartas jesuíticas do Brasil. Nóbrega - 1549-1558. Rev. Inst. Est. Bras., v. 38, p. 87-119, 1995.

HANSEN, J. A. A escrita da conversão. In: COSTIGAN, L. H. (Org.). Diálogos da conversão: missionários, índios, negros e judeus no contexto ibero-americano do período barroco. Campinas: Editora da Unicamp, 2005.

HERNANDES, P. R. A Companhia de Jesus e o Brasil do século XVI. Revista HISTEDBR On-line, n. 40, p. 222-244, 2010. Disponível em: <http://www.histedbr.fe.unicamp.br/revista/edicoes/40/art14_40.pdf>. Acesso em: dez. 2015.

HERNANDES, P.R. O teatro de José de Anchieta: arte e Pedagogia no Brasil Colônia. Campinas, SP: Editora Alínea, 2008.

JULIA, D. A cultura escolar como objeto histórico. Revista Brasileira de História da Educação, n. 1, p. 9-43, 2001.

LEITE, S. S. J. História da Companhia de Jesus no Brasil. Tomo I e II. Livro I. São Paulo: Edições Loyola, 2004.

LEITE, S. S. J. Cartas dos primeiros jesuítas do Brasil - 1538-1553. São Paulo: Comissão do IV Centenário da Cidade de São Paulo, 1954a. v. 1. 
LEITE, S. S. J. Cartas dos primeiros jesuítas do Brasil - 1553-1558. São Paulo: Comissão do IV Centenário da Cidade de São Paulo, 1954b. v. 2.

LEITE, S. S. J. Cartas dos primeiros jesuítas do Brasil - 1558-1563. São Paulo: Comissão do IV Centenário da Cidade de São Paulo, 1954c. v. 3.

LEITE, S. S. J. História da Companhia de Jesus no Brasil. Organização de César Augusto dos Santos et al. São Paulo: Edições Loyola, 2004. v. 1.

LOYOLA, Inácio (1966). Exercícios Espirituais. Orientou a tradução e fez anotações: Pe Géza Kövecses S. J. 3a . ed.. Porto Alegre, 1966.

MANACORDA, M. A. História da Educação: da Antiguidade aos nossos dias. Trad.

Gaetano Lo Monaco. 12a ed. São Paulo: Cortez, 2006.

NÓBREGA, M. Cartas do Brasil (1549-1560). Belo Horizonte: Itatiaia: São Paulo: Editora Universidade de São Paulo, 1988.

PAIVA. J. M. Educação jesuítica no Brasil Colonial. In: LOPES, E. M. T. et al. (Org.) 500 anos de educação no Brasil. 2 ed. Belo Horizonte: Autêntica, 2000. p. 43-59.

POMPA, C. Religião como tradução: missionários, Tupi e Tapuia no Brasil colonial. Bauru: EDUSC/ANPOCS, 2003.

SAVIANI, D. História das idéias pedagógicas no Brasil. 2.ed. Campinas: Autores Associados, 2008.

TODOROV, T. A conquista da América: a questão do outro. Tradução Beatriz PerroneMoisés. 4. ed. São Paulo: WMF Martins Fontes, 2010.

VAINFAS, R. A heresia dos índios: catolicismo e rebeldia no Brasil colonial. São Paulo: Companhia das Letras, 1995.

VASCONCELOS, S. V. Crônica da Companhia de Jesus; introdução de Serafim Leite. $3^{\text {a }}$ ed. Petrópolis, Vozes; Brasília, 1977. de Serafim Leite, S.I. Rio de Janeiro - Imprensa Nacional. 1943.

\footnotetext{
${ }^{1}$ Mestranda em Educação no Programa de Pós Graduação em Educação da Universidade Federal de AlfenasMG.

${ }^{2}$ Professor do Programa de Pós-Graduação em Educação da Universidade Federal de Alfenas- MG.

${ }^{3}$ A Companhia de Jesus foi fundada por Inácio de Loyola, um soldado que, após ter sido ferido em uma batalha e atingido na perna, teve de passar por um momento de grande repouso para recuperação. No local em que estava a se recuperar, Loyola pediu por livros que tratassem de cavalaria para diminuir a ânsia de esperar pela recuperação; entretanto, só havia livros que falavam da vida dos santos e da vida de Jesus Cristo neste local, e ele os leu. Passou então por um profundo processo de conversão e iniciou o processo de produção dos Exercícios Espirituais, e mais adiante fundou a Companhia de Jesus com a função de criar "soldados para Cristo" (LEITE, 2004, p. 3-4).

${ }^{44}$ A interpretação das cartas sobre a resistência dos nativos é feita a partir da hermenêutica do que relataram os missivistas jesuítas e alguns outros cronistas da época, também colonizadores. No caso das cartas jesuíticas, a interpretação do que acontecia com os índios ainda é limitada porque os manuscritos, ao serem recuperados para impressão, foram alterados por Serafim Leite.

${ }^{5}$ No caso dessa forma de resistência indígena, a Santidade de Jaguaribe, Vainfas (1995) interpretou os documentos produzidos pelo Tribunal da Inquisição que se instalou na Bahia para investigar essa santidade. Nesse caso, foram colhidos alguns relatos de índios e mestiços. Mas, também a escrita desses documentos e o crivo são de Heitor Furtado, que presidiu o tribunal que investigou a seita.
} 
${ }^{6}$ Clastres (1995) conviveu com os índios Guayaki de Mato Grosso e do Paraguai, nos anos 1970, e percebeu que mesmo totalmente aceito e adaptado entre eles, vivendo como um deles, alguns rituais não o deixavam participar. Chegou a inferir por alguns relatos que esses índios ainda praticavam a antropofagia, mas ocultaram dele por muito tempo. Medo da represália aos seus costumes? Não soube afirmar. Fez, então, uma relação desse ocultamento, desse silenciamento dos índios, com alguns relatos que havia lido nas cartas jesuítas, inferindo que também os índios aldeados daquele período, séculos XVI e XVII, ocultavam práticas que lhes eram caras e as quais eram repreendidas pelos jesuítas, nas letras, e pelo Governador, nas armas.

${ }^{7}$ No caso de Todorov (2010), a investigação sobre esse modo de resistência indígena é produzida pelo relato de um cronista, padre dominicano, que conhecia bem a vida e os costumes dos índios por ter vivido desde a infância entre eles e que desconfiava e se desesperava com o modo como os índios aderiram à religião cristã, misturando aspectos de sua cultura com os ritos cristãos.

${ }^{8}$ A terra em que tudo é produto da abundância sem que seja necessário trabalhar, onde se goza de perpétua juventude, etc. - o advento dela que prometem. São eles os fiadores de que ela é possível aqui e agora, pois podem comprometer-se a conduzir os outros até lá (...) o saber dos profetas consiste em possuir a chave desse novo lugar: eles conhecem o caminho da Terra sem Mal, o que não quer dizer propriamente sua localização geográfica, mas sim as regras éticas, únicas a propiciarem o acesso a ela (CLASTRES, 1978, p. 47).

${ }^{9}$ As cartas jesuíticas, além da importância como meio de comunicação, permitiam o controle administrativo das colônias. Existiam cartas destinadas ao rei, com esse intuito de prestar contas e informar sobre a missão nas terras brasílicas, e também as que eram destinadas a irmãos que se encontravam em outras regiões ou até mesmo cartas destinadas a um público amplo, com intuito de evangelização. Segundo Hansen (1995), as cartas de Nóbrega, por exemplo, mostravam um diálogo que mesclava familiaridade com sacralidade, utilizando-se de saudações comuns como: "A graça e o amor de N. Senhor Jesus Christo seja sempre em nosso favor e ajuda. Amen.” (HANSEN, 1995, p. 92)

Recebido: $\quad$ março-16 $\quad$ Aprovado: setembro-16 